\title{
The Role of Canon Law in the Ecumenical Venture: a Roman Catholic Perspective
}

\author{
BRENDAN LEAHY ${ }^{1}$ \\ Professor of Systematic Theology, St Patrick's College, Maynooth \\ Secretary to the Advisory Committee on Ecumenism of the Irish Bishops' Conference
}

\begin{abstract}
One of the main goals of the Second Vatican Council (the 5oth anniversary of whose opening will be celebrated in 2012) was the unity of all Christians. Not least among its achievements was the fact that it launched the Catholic Church into the Ecumenical Movement and also paved the way for a global revision of the Church's Code of Canon Law. This article reflects from a Roman Catholic perspective on aspects to do with canon law and ecumenism. It does so in the light of the Council's teaching and reception. Conciliar hermeneutics and questions left open at the Council are considered. In conclusion, the author suggests that greater attention to the Church's charismatic principle and missionary mandate underlined at the Council offers wide scope for continuing exploration among Anglican and Roman Catholic canonists in the cause of unity.
\end{abstract}

\section{INTRODUCTION}

In his report on the decade of colloquia of Anglican and Roman Catholic canon lawyers, Mark Hill rightly reminds us that 'given its thoroughly theological nature and its capacity to order and facilitate Christian life and mission [canon law] definitely has its place in ecumenical dialogue and activity' between Anglican and Roman Catholics. ${ }^{2}$ This is so not least because of a common legal heritage, profound existing similarities and possible future convergences. And yet oddly the topic of comparative canon law has been something of a missing link in ecumenical dialogue. The dominant force to date has been primarily theological on the level of official dialogue, while pastoral and spiritual on the level of grass-roots ecumenism. Canonical factors deserve to be explored further to see in what way they can open up ideas, perspectives and avenues for further ecumenical developments on the level of institutional relations.

In this article I propose to reflect on some aspects of the role of canon law in the ecumenical venture from a Roman Catholic perspective. In doing so,

2 'A Decade of Ecumenical Dialogue on Canon Law', (2009) 11 Ecc LJ 284-328, p 296. 
reference to the Second Vatican Council has to be paramount. And the Code of Canon Law is central. In the Catholic understanding, codification is a legitimate and helpful instrument in the concrete realization and application of the gospel and ecclesial doctrines within the body of the Church and in its everyday life. It helps build up communion and avoid confusion. In this sense, canon law has served the difficult task of formulating the conciliar doctrine in canonical form. In the continuing dialogue among canonists I want to suggest themes that can be considered, concluding with a suggestion that the dialogue between Anglican and Roman Catholic canon lawyers might gain also from exploration of the conciliar themes such as the Church's charismatic principle and mission ad extra. ${ }^{3}$

\section{CANON LAW AND THE RECEPTION OF VATICAN II}

The Second Vatican Council is the Pentecostal event that continues to guide the Catholic Church. It provides the magisterial and theological 'compass' and is the 'essential and fundamental Magna Charta' of the Church today. ${ }^{4}$ Taking into account Vatican II's stated pastoral and ecumenical goals, all conciliar documents have to be read through an ecumenical lens. ${ }^{5}$ On the basis of the Council it is clear that the Church in its teaching, acting and juridical activities is expected to be guided by the will to do all it can to promote the unity of Christians. ${ }^{6}$ The Groupe des Dombes, in fact, reminds us that the Council texts cannot be limited to a gospel-oriented perspective of personal conversion. An institutional renewal was also intended. ' It could be said that through the Council what the 'Spirit is saying to the churches' (cf Revelation 2:7) is to review both personal and institutional life to ensure all ecclesial life is more conducive to the unity of the Church. ${ }^{8}$

3 In my research particularly for the first part of this article I have drawn on Cardinal Kasper's reflection on precisely this theme. He is one of the Catholic Church's most accomplished theologians and former President of the Pontifical Council for the Promotion of Christian Unity. See W Kasper, 'Canon Law and Ecumenism,' The Jurist 69 (2009) 171-189.

4 See John Paul II, Apostolic Letter at the Beginning of the New Millennium, Novo Millennio Ineunte (6 January 2001), n 57 and Pope Benedict XVI's dialogue with the clergy of the diocese of Belluno-Feltre, Treviso, 24 July 2007.

5 See Pope John Paul II's Encyclical on Commitment to Ecumenism, Ut Unum Sint (25 May 1995), n 8.

6 The 'Harvesting the Fruits' project was launched by the Pontifical Council for Promoting Christian Unity to review the fruits of forty years of ecumenical dialogues since the Second Vatican Council. See W Kasper, Harvesting the Fruits: Basic Aspects of Christian Faith in Ecumenical Dialogue (London, 2009).

7 See Groupe des Dombes, Pour la Conversion des 'Eglises': identité et changement dans la dynamique de communion (Paris, 1991). English translation: For the Conversion of the Churches (Geneva, 1993). See also the reference to a 'change of heart' in the Second Vatican Council's Decree of Ecumenism, Unitatis Redintegratio, 7 and Ut Unum Sint, 15, implying collective conversion as well as personal conversion.

8 See studies published in (1999) 59 The Jurist 329-468 and (2004) 64 The Jurist 1-360. 
Leading authorities have reiterated that the Catholic Church is irrevocably committed to the Council's agenda of promoting the unity of Christians. ${ }^{9}$ In the process of reception of the Council, ecclesiology and ecumenism are intimately bound together. Already during the Council this connection was underlined. When presenting the schema of the Decree on Ecumenism, Bishop Joseph Martin in the relatio said: 'Our Decree in every way and evidently presupposes the doctrine set forth in the Dogmatic Constitution de Ecclesia'. ${ }^{\circ}$ Pope Paul VI spoke of the Decree 'completing' the Constitution on the Church."

While Catholics may not advertise it, canon law has played and continues to play a key role in the reception of conciliar doctrine that brings ecclesiology and ecumenism together. The promulgation of the 1983 Code of Canon Law was a very significant step. The drafters of the 1983 Code have to be admired for their great achievement. Having to formulate laws in the light of Vatican II's texts was not easy. A key task was that of identifying the ecclesiological doctrine of the Council and then searching for a fitting juridical structure. There were inevitable issues surrounding interpretation of the Conciliar texts. ${ }^{12}$ Choices had to be made. Theological positions had to be adopted.

In the apostolic constitution Sacrae disciplinae leges whereby Pope John Paul II promulgated the 1983 Code, it is stated that the Code is to express Vatican II and its ecumenical purpose as far as it can. ${ }^{13}$ The image of the Church outlined in Vatican II is to be the primary pattern that canon law takes as its inspiration. Commenting on the great effort to translate the conciliar doctrine into canonical language, the Pope added, 'if, however, it is impossible to translate perfectly into canonical language the conciliar image of the Church, nevertheless, the Code must always be referred to this image as the primary pattern whose outline the Code ought to express insofar as it can by its very nature.. 4 The Pope highlighted the elements that characterise the 'substantial newness' of the Council regarding the image of the Church it presented: the doctrine of the Church as the people of God, hierarchical authority as service, the doctrine of the Church as communio, and the doctrine that all members of the people of God participate in the threefold ministry of Christ. He also counted commitment to ecumenism as an element of the substantial newness.

While acknowledging the positive role canon law plays in translating magisterial and theological doctrine into juridical form, it cannot be denied that

10 Acta Synodalia Concilii Vaticani Secundi II/5, p 473.

11 See F Sullivan, 'The Decree on Ecumenism: Presuppositions and Consequences', (1990) 26 One in Christ 7-19.

12 Other documents published after the Council that have a direct bearing on ecumenism are listed in the Directory for the Application of Principles and Norms on Ecumenism published by the Pontifical Council for the Promotion of Christian Unity (London, 1993), fn 3, p 7. Ibid. 
several interesting questions open up for further exploration among canon lawyers, and between canon lawyers and theologians. How does the essential organic unity of theology and canon law work? Do canon lawyers simply translate the doctrine into juridical terms or are they doing something more? Are they actually directing the process of the transmission of doctrine in a particular direction? Cardinal Kasper puts it as follows: 'one may ask: in what sense and to what degree can and must canon law be understood as a juridical interpretation and application of church doctrines? Or can one perhaps note a transformation from one level to another level through canon law, a displacement that is not simply terminological? ${ }^{15}$ In terms of the process of the reception of Vatican II, the question arises as to what extent the juridical formulations are to be considered as the 'authoritative' and 'authentic' theological interpretation of the Council. The Council is clearly the point of reference for interpreting the Code but 'in what sense and at what level ... does the Code become normative for the interpretation of the Council?"16 The whole area of understanding how to translate the Gospel and ecclesial doctrines into juridical terms is a rich mine to be quarried together. ${ }^{17}$

The Code, in fact, took up the positive and optimistic outlook of the Council, prohibiting much less than the 1917 Code, suggesting and encouraging positive behaviour. See, for instance, the difference between canon 731 of the 1917 code and canon 844 of the 1983 code. And yet, in Sacrae disciplinae leges, Pope John Paul recognised there would be difficulties in translating conciliar doctrine into canon law in that Vatican II drew both new and old from the treasury of tradition. He proposed the way forward was fidelity in newness and newness in fidelity. On this basis Cardinal Kasper concludes: 'therefore the codification and the subsequent legal activity of the Church cannot be limited to looking backwards to the vetera but have to take into account also the new thrusts and orientations of the Council'. ${ }^{18}$

\section{CANON LAW AND CONCILIAR HERMENEUTICS}

The Second Vatican Council with its ecumenical agenda remains the benchmark for canon lawyers in the Catholic Church as they go forward in their activities of interpreting, applying and drafting the law. A key issue for consideration in these tasks is conciliar hermeneutics. Canonical language and juridical terms have to be crafted in the light of the magisterial and theological doctrines.

See Kasper, 'Canon Law and Ecumenism', p 172.

Ibid, p 182.

See the position of Rudolf Sohm taken up by Karl Barth, E Wolf and Hans Dombois. Catholic authors writing in this area include Klaus Mörsdorf, Antonio Rouco Varela, Eugenio Coreccio and Libero Gerosa.

18 Kasper, 'Canon Law and Ecumenism', p 175. 
The process of identifying doctrines and then finding a fitting juridical structure happens every time universal or particular laws have to be drafted or applied. Listening with one ear to the juridical language, the canon lawyer has always to make sure in applying the law to specific cases that he or she is listening with the other ear to the conciliar doctrine.

A number of guidelines for interpreting conciliar doctrine can be formulated. Offering a word of advice to canon lawyers, Cardinal Kasper remarks: 'Experts in canon law who are conscious of the fact that not all texts - even within a certain document - have the same binding authority ought to be particularly attentive to this when they refer to a specific passage in a conciliar document ${ }^{\prime}{ }^{19}$ In traditional Catholic theology different degrees of binding character among doctrinal statements are recognised. ${ }^{20}$ The notion of the 'hierarchy of truths' mentioned in Unitatis Redintegratio ${ }^{21}$ is important in this context.

Following traditional theological rules for interpreting texts, it is not sufficient merely to read and study the text of the documents in their final version. It is also necessary to attend to the historical development of the documents, noting the reason for the changes, omissions and additions during the conciliar debates. An example would be the change from the 'the Church of Christ is (est) the Catholic Church' to 'the Church of Christ subsists (subsistit) in the Catholic Church' in the Council's constitution on the Church, Lumen Gentium 8, a text over which rivers of ink have been poured in scholarly writings.

A classic traditional rule of interpreting a particular conciliar text is to refer to the anathemas associated with it. However, this cannot apply to Vatican II because it was not convoked to settle doctrinal controversies. The documents of Vatican II cannot be read in isolation but have to be considered within the context of the whole corpus of conciliar documents and in the light of the purposes of the Council. The reception of the text in subsequent magisterial teaching is of fundamental importance in interpreting the Council. That teaching is itself an interpretation, clarification and elucidation of the Council. As we shall see below, linked to this is the delicate issue of the place of developments since the Council in the theological insights that lay behind the intentions of the Council.

Cardinal Kasper provides us with examples of some of the points made above. In the Council, for instance, in view of its ecclesiology of communion with varying degrees of participation, the question of the appropriateness of using the word 'member' of the Church arose. Cardinal Bea proposed that a terminology was needed that would allow for various nuances of belonging to the Church of Christ. This was accepted in the Council debates and so the word 'member' 
was removed from one of the drafts and replaced by expressions such as 'those who belong fully to the Catholic Church' (Lumen Gentium, 14) or coniungere (Lumen Gentium, 15). The legislator of the Code took this change into account and omitted the word 'member' (see canon 205 and canon 11). Kasper points out that drafters of particular laws for instance in the area of mixed marriages need to be careful lest they fall back on this and use statements such as 'only members of the Catholic Church may ...' instead of 'those who belong fully to the Catholic Church may ....

Another example is the expression 'ecclesial communities'. After much discussion and various drafts it was decided at the Council that the word 'communities' on its own in chapter three of the Decree on Ecumenism was not sufficient. Instead, the expression 'ecclesial communities' was adapted to cover communities which have preserved from the common apostolic patrimony elements that have true ecclesial character. The Council states: 'Indeed the Spirit of Christ has not refrained from using these ecclesial communities as means of salvation'. ${ }^{22}$ In canon $1183 \sqrt{3}$ on funerals for baptized

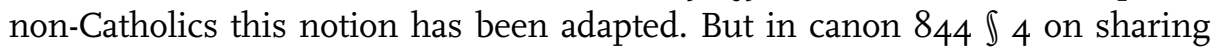
the Eucharist, the sacrament of penance, and the anointing of the sick with other Christians, the Code uses only the word communitates without the adjective ecclesiales. The corresponding canon in the Oriental Code of Canon Law (canon $671 \llbracket 4$ ) does have the term communitates ecclesiales. Kasper comments 'the addition of the adjective ecclesiales would have contributed to the correct understanding of the Council's approach and would have facilitated the reception of the conciliar doctrine which emphasizes that the Spirit works within and through these communities'. ${ }^{23}$

The style of expression adopted by Vatican II is also significant in its hermeneutics. In general what we find is that the Council tried to emphasize what unites and not what divides, putting the focus first on what Christians have in common and then the existing differences that often end up in secondary clauses. The Church, of course, has to be clear in its statements, but sensitivity especially in questions that are particularly delicate to non-Catholic Christians is needed. The rule should be, as Cardinal Kasper puts it, 'fortiter in re, suaviter in modo'. Again he states, 'in drafting canonical norms we need to recognize whether a particular formulation can be perceived as hard or as welcoming and whether it is characterized by a spirit of reconciliation'. ${ }^{24}$ The Council intended to speak an 'ecumenically-friendly language'. ${ }^{25}$ Attempts to simply 
preserve Catholic identity by emphasizing what differentiates and separates are to be avoided.

The actions of the Council are worth noting in any consideration of conciliar hermeneutics. Perhaps they suggest how to go about formulating doctrine and laws in an ecumenical spirit. During the Council observers from other churches and ecclesial communities were present and involved in discussions, giving their opinion as representatives of their churches. The 'ecumenical exchange of gifts ${ }^{26}$ was a source of reciprocal enrichment. ${ }^{27}$

\section{OPEN QUESTIONS - EVOLVING CONCEPTS}

The Second Vatican Council intentionally left open certain questions for further theological exploration and research. The notion of communion is one such issue. This has become a central category in Catholic ecclesiology. ${ }^{28}$ Yet study of the Conciliar texts reveals that the notion of communion has different levels of meaning. The task of achieving necessary clarifications was left to postconciliar theological discussion. This raises the question as to how interpretation of the law, application of the law and drafting of new laws in the light of a theology of communion needs to be mindful of post-conciliar theological developments. Cardinal Kasper comments, 'A correct interpretation, therefore, must take account not only of the tradition but must also be aware of the rich and innovative potential for the future contained in the conciliar texts' ${ }^{29}$

Another question left open is the difference between a church and an ecclesial community. The relatio on the third chapter of Unitatis Redintegratio explicitly stated it was not getting into this question. ${ }^{30}$ The Council decided it did not want to make a list of which groups of Christians belonged to what category. Cardinal Kasper notes that canon 844 on Eucharist, penance and anointing of the sick has given its interpretation of the 'open-ended' formulation of Unitatis redintegratio, when it says that in some cases and in precise circumstances communicatio in sacris is possible and even advisable. ${ }^{31}$ Cardinal Kasper asks: what does it mean when 'open-ended' theological terms in conciliar texts now appear in canonical texts and assume a juridical meaning which does not go against the council's interpretation but goes beyond it in a reductive fashion? Certainly, 'open-ended conciliar terms such as "ecclesial communities"

See Lumen Gentium, 13, Ut Unum Sint 28, 57.

See Unitatis Redintegratio, 4.

See W Kasper, 'Communio: The Guiding Concept of Catholic Ecumenical Theology' in That They May All Be One (London, 2004), 50-74. See also J Renken, “Duc in Altum!” Communio: Source and Summit of Church Law', (2003) 63 The Jurist 22-69.

Kasper, 'Canon Law and Ecumenism', p 180.

See AS III/IV, 14; AS II/VII, 35.

Unitatis Redintegratio n 8. 
and "church" cannot be interpreted solely in a juridical way without recourse to continually developing post-conciliar theology'.32

\section{THE CHURCH'S CHARISMATIC DIMENSION}

In Catholic theology, the role of the Holy Spirit in the Church has gained new attention in recent years. Undoubtedly, one of the major fruits of the Council was a rediscovery of the charismatic dimension of the Church. ${ }^{33}$ By interpreting its norms in agreement with the Council's doctrine and purpose, and by applying them with a respect for the will of the Lord expressed to his disciples 'that all may be one' (John 17:21) canon law is very much involved in fostering the Holy Spirit's work in the Church. ${ }^{34}$ Nevertheless it has been pointed out that canon law is 'one of the places in the life of the Church where the truth of pneumatology has yet to be confirmed' ${ }^{35}$

It is helpful in ecumenical dialogue to recognise the double polarity of the Church's life, what Hans Urs von Balthasar calls 'objective' and 'subjective' sanctity. Canon law serves what we might call the objective dimension of the Church's transmission of all that she is and believes. From the beginning, under the prompting of the Holy Spirit, adherence to the event of Christ as an event of truth, transmitted in scripture and tradition, has been shaped in some fashion by law. The Christ event is handed on in the tradition through the objective means of the Word proclaimed, the sacraments 'rightly administered' and the ministry; and that also includes law. It could be said that to date ecumenical dialogue has focused primarily on issues relating to these objective means of holiness, so we have documents on the Eucharist, priesthood, ministry and authority.

Canon law, however, also serves the subjective dimension of the Church's appropriation in the Spirit of the transmission of the evangelical life that comes from the Christ event and passed on through Apostolic Succession understood in its broadest sense. While expressing something in law does not necessarily assure practice in life, nevertheless canon law can motivate, enlighten and guide ecumenical activity on the level of the Church's charismatic dimension. Perhaps more reflection is needed here in terms of spiritual ecumenism, the ecumenism of life and the ecumenism of the people. How can canon law best carry out its educational role in fostering and facilitating the ecumenism of life that arises from the Church's charismatic principle?

A German canonist, Christoph Hegge, points out that if canon law is to express the law of the Spirit it must do so also taking into account the

32 Kasper, 'Canon Law and Ecumenism', p 181.

33 See Lumen Gentium 4 and 12.

34 See Kasper, 'Canon Law and Ecumenism', p 189.

35 See J Coriden, 'The Holy Spirit and Church governance,' (2006) 66 The Jurist 339-373 at 354. 
charismatic aspects that have come to life within the Church. ${ }^{36}$ He is thinking for instance of new ecclesial movements. While the Holy Spirit is a living presence in the whole Church, Vatican II recognises there are 'concentrated' experiences of his presence of which charisms are a part. Contrary to what is true of the structure of modern states, the constitution of the Church is not identifiable with the institution alone. Charisms are constitutive of the Church's nature. They express the relevancy and dynamic of renewal of the Spirit within the Church. ${ }^{37}$

The new ecclesial movements that have grown up in the past century, 'associations of the faithful' as they are called in the Catholic Church, are often laboratories of the ecumenism of life and spiritual ecumenism. The canonist Jean Beyer has written that it is as if the movements have been created precisely to enable people understand and experience the ecclesiology of Vatican II. ${ }^{8}$ All of this is an area where canon law has much to offer in exploring further how ecumenical life in common can be promoted in these new forms of ecclesial life. ${ }^{39}$

\section{MISSION}

To grow together in unity and mission was the focus of the International Anglican - Roman Catholic Commission for Unity and Mission (IARCCUM). Perhaps in consideration of canon law's contribution to the ecumenical venture, there is a risk of devoting too much attention to the ad intra questions of ecclesiology. The Second Vatican Council's deep yearning for the evangelisation of the contemporary world culminated in the missionary decree Ad Gentes but runs through all the documents of the Second Vatican Council. The Pentecostal event was very much directed towards mission ad extra. ${ }^{\circ}$

Mission was not presented as a separate propaganda activity. What comes across in the Council is that it is precisely as a new people of God (born in the 'mystery' revealed in Jesus Christ) and as a sacrament and sign of communion that the Church, transparent to Jesus Christ, is 'sure seed of unity, hope and salvation for the whole human race' ${ }^{\text {'1 }}$ and as such 'realizes that it is truly

C Hegge, Rezeption und Charisma (Würzburg, 1999) and Il Vaticano II e i Movimenti Ecclesiali: Una Recezione Carismatica (Rome, 2001).

7 See Eugenio Corecco on the need to reflect more on the juridical value of charisms, 'Aspects of the reception of Vatican II in the code of canon law,' in G Alberigo, J-P Jossua and J Komonchak (eds), The Reception of Vatican II. Translated by M O'Connell (Washington, 1987), 249-296, at 266.

8 See J Beyer, 'I “movimenti ecclesiali”', (1987) 23 Vita Consacrata 143-156, at 156.

On the reception of the Council see further Hermann J Pottmeyer, 'A new phase in the reception of Vatican II: twenty years of interpretation of the Council' in Alberigo, Jossua and Komonchak (eds) The Reception of Vatican II, pp 27-43.

Decree on the Missionary Activity of the Church, Ad Gentes, 5.

Lumen Gentium, 9. 
linked with humankind and its history by the deepest of bonds'. ${ }^{42}$ The interaction of the themes of mystery, communion and mission run throughout the Council. These themes have much to offer Anglican and Roman Catholic canon lawyers as they explore further canonical issues to do with co-operation in mission, evangelisation and inter-faith dialogue.

\section{CONCLUSION}

Yves Congar has written that the sentence from Matthew's Gospel, 'For where two or three are gathered in my name, I am there among them'43 can be considered a key text of the Second Vatican Council, not so much in terms of the number of times it is quoted but as expressing the heart of what the Council intended. The presence of Christ in our relating to one another is central to the mission of the Church. What we have understood more in recent decades is that we are not saved as individuals but together, as people in relationship, as social beings. None of our institutions, communities or initiatives are stand-alone. Everything and everyone is in some way in relationship with everything and everyone else. Law becomes a valuable and essential instrument of this fraternal communion in Christ. The task for canon law is to provide structures and point to customs that allow the Holy Spirit to foster our common life in communion embraced within the Law of the people of God: mutual love. ${ }^{44}$

By way of conclusion it is appropriate to suggest a framework for the explorations between Anglican and Roman Catholic lawyers. It is one indicated by Pope John Paul II ten years ago. In his apostolic letter, Novo Millennio Ineunte, he saw the promotion of a spirituality of communion as an urgent task facing all of us. The temptation, he commented, is to run immediately into actions that need to be undertaken or programmes to be established. But what's needed for great ecclesial maturity that leads to greater ecumenical dialogue is to learn together day by day in the bits and pieces of life to live 'a spirituality of communion', making it the guiding principle that can be shared wherever ministers, pastoral workers, families and communities are relating to one another. Presumably, therefore, canon lawyers are included.

In what is perhaps the most powerful description of communion in terms of brotherly/sisterly love as Jesus proposed, ever found in a Magisterial text addressed to the whole Church, Pope John Paul II, taking up the vision of Vatican II, explains key features of this communitarian spirituality. First of all it involves 'the heart's contemplation of the mystery of the Trinity dwelling in us, and whose light we must also be able to see shining on the face of the 
brothers and sisters around us.' So to covenant with one another to share that one glance of our heart on the mystery of the Trinity that dwells within us and in which, through grace, we already in some way share in our mutual relations with one another. A spirituality of communion also means 'an ability to think of our brothers and sisters in faith within the profound unity of the Mystical Body, and therefore as "those who are a part of me".' Here the Pope underlines a new 'thinking' and 'feeling' in terms of sharing with others 'their joys and sufferings ... their desires and ... their needs'. This means offering deep and genuine friendship. On the basis of the theologal dimension of charity, a spirituality of communion implies also 'the ability to see what is positive in others, to welcome it and prize it as a gift from God: not only as a gift for the brother or sister who has received it directly, but also as a "gift for me".' Finally, the Pope points to another 'ascetism', that of knowing how to 'make room' for our brothers and sisters, bearing 'each other's burdens' 45 and resisting the selfish temptations which constantly beset us and provoke competition, careerism, distrust and jealousy.

The life of communion needs to be worked at and extended day by day and at every level in the structures of each level of the Church's life - in relations between all ordained ministers, between the ordained and the laity, between religious communities as well as between associations and ecclesial movements. In striking fashion, the Pope concludes: 'Let us have no illusions: unless we follow this spiritual path, external structures of communion will serve very little purpose. They would become mechanisms without a soul, "masks" of communion rather than its means of expression and growth. ${ }^{46}$ Canon law is surely a significant player in the expression and growth of communion within the Catholic Church as well as between Anglican and Roman Catholics. 